\title{
Observational constraints on the global atmospheric budget of ethanol
}

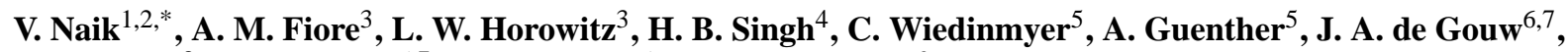 \\ D. B. Millet $^{8}$, P. D. Goldan ${ }^{6,7}$, W. C. Kuster ${ }^{6}$, and A. Goldstein ${ }^{9}$ \\ ${ }^{1}$ Woodrow Wilson School, Princeton University, NJ, USA \\ ${ }^{2}$ Program in Atmospheric and Oceanic Sciences, Princeton University, NJ, USA \\ ${ }^{3}$ Geophysical Fluid Dynamics Laboratory, NOAA, Princeton, NJ, USA \\ ${ }^{4}$ NASA AMES, Moffett Field, CA, USA \\ ${ }^{5} \mathrm{NCAR}$, Boulder, CO, USA \\ ${ }^{6}$ NOAA Earth System Research Laboratory, Boulder, CO, USA \\ ${ }^{7}$ Cooperative Institute for Research in Environmental Sciences, University of Colorado, Boulder, CO, USA \\ ${ }^{8}$ Department of Soil, Water and Climate, University of Minnesota, St. Paul, MN, USA \\ ${ }^{9}$ University of California at Berkeley, Department of Environmental Science, Policy and Management, CA, USA \\ *now at: High Performance Technologies Inc./Geophysical Fluid Dynamics Laboratory, NOAA, Princeton, NJ, USA
}

Received: 20 December 2009 - Published in Atmos. Chem. Phys. Discuss.: 18 January 2010

Revised: 20 May 2010 - Accepted: 7 June 2010 - Published: 17 June 2010

\begin{abstract}
Energy security and climate change concerns have led to the promotion of biomass-derived ethanol, an oxygenated volatile organic compound (OVOC), as a substitute for fossil fuels. Although ethanol is ubiquitous in the troposphere, our knowledge of its current atmospheric budget and distribution is limited. Here, for the first time we use a global chemical transport model in conjunction with atmospheric observations to place constraints on the ethanol budget, noting that additional measurements of ethanol (and its precursors) are still needed to enhance confidence in our estimated budget. Global sources of ethanol in the model include 5.0 $\mathrm{Tg} \mathrm{yr}^{-1}$ from industrial sources and biofuels, $9.2 \mathrm{Tg} \mathrm{yr}^{-1}$ from terrestrial plants, $\sim 0.5 \mathrm{Tg} \mathrm{yr}^{-1}$ from biomass burning, and $0.05 \mathrm{Tg} \mathrm{yr}^{-1}$ from atmospheric reactions of the ethyl peroxy radical $\left(\mathrm{C}_{2} \mathrm{H}_{5} \mathrm{O}_{2}\right)$ with itself and with the methyl peroxy radical $\left(\mathrm{CH}_{3} \mathrm{O}_{2}\right)$. The resulting atmospheric lifetime of ethanol in the model is 2.8 days. Gas-phase oxidation by the hydroxyl radical $(\mathrm{OH})$ is the primary global sink of ethanol in the model (65\%), followed by dry deposition (25\%), and wet deposition (10\%). Over continental areas, ethanol concentrations predominantly reflect direct anthropogenic and biogenic emission sources. Uncertainty in the biogenic ethanol emissions, estimated at a factor of three, may contribute to
\end{abstract}

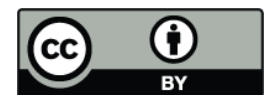

Correspondence to: V. Naik (vaishali.naik@noaa.gov) the $50 \%$ model underestimate of observations in the North American boundary layer. Current levels of ethanol measured in remote regions are an order of magnitude larger than those in the model, suggesting a major gap in understanding. Stronger constraints on the budget and distribution of ethanol and OVOCs are a critical step towards assessing the impacts of increasing the use of ethanol as a fuel.

\section{Introduction}

The use of bio-ethanol (ethanol derived from biomass) is currently being promoted as a renewable fuel that will alleviate dependence on fossil fuels and combat global warming. Future increases in ethanol emissions may impact the oxidizing capacity and the ozone-forming potential of the atmosphere (Singh et al., 2001). High levels of ethanol have been measured in the boundary layer in urban (ranging from 0.4 to 240 ppbv) (Grosjean et al., 1998; Nguyen et al., 2001; Millet et al., 2005), rural (0.04-0.4 ppbv) (Millet et al., 2004, 2006], and remote (0.02-0.2 ppbv) (Singh et al., 2001) atmospheres. While ethanol-gasoline blended fuels have been advocated for reducing carbon monoxide emissions (Poulopoulos et al., 2001), their combustion also increases ambient levels of acetaldehyde and peroxyacetyl nitrate (PAN) (Tanner et al., 1988; Knapp et al., 1998; Jacobson, 2007), both of

Published by Copernicus Publications on behalf of the European Geosciences Union. 
Table 1. Global atmospheric budget of ethanol using MOZART-4. Numbers in parentheses show the percentage contribution of each source/sink to the total source/sink of ethanol.

\begin{tabular}{llll}
\hline & BASE & SYNEOH & Singh et al. (2004) \\
\hline Sources $\left(\mathrm{Tg} \mathrm{yr}^{-1}\right)$ & & & \\
Industrial & $3.2(21 \%)$ & $3.2(7 \%)$ & $2(16.6 \%)$ \\
Biofuel & $1.8(12 \%)$ & $1.8(4 \%)$ & \\
Biogenic & $9.2(63 \%)$ & $9.2(21 \%)$ & $6(50 \%)$ \\
Biomass Burning & $0.47(3 \%)$ & $0.47(1 \%)$ & $2(16.6 \%)$ \\
Atmospheric in-situ production & $0.06(<1 \%)$ & $0.06(<1 \%)$ & $2(16.6 \%)$ \\
Missing Source & & $29.3(66 \%)$ & \\
Total Source & 14.7 & 44.0 & 12.0 \\
Sinks (Tg yr & & & \\
Oxidation by OH & & $33.5(77 \%)$ & \\
Wet Deposition & $9.6(65 \%)$ & $5.0(11 \%)$ & \\
Dry Deposition & $1.4(10 \%)$ & $5.2(12 \%)$ & \\
Total Sink & $3.7(25 \%)$ & 44.0 & $0.12^{\mathrm{a}}$ \\
Global Burden (Tg) & 14.7 & 0.68 & $\sim 3.5$ \\
Atmospheric Lifetime (days) & 0.11 & 5.7 & \\
\hline
\end{tabular}

a Estimated as total source multiplied by the atmospheric lifetime.

which are toxic and contribute to ozone pollution. Ethanol may also act as a precursor to secondary aerosols (Blando and Turpin, 2000). A robust understanding of regional and global budgets of ethanol is necessary to evaluate the air quality and climate impacts of projected future increases in ethanol emissions.

A preliminary analysis of the global ethanol sources based on aircraft measurements in March-April 2001 over the North Pacific off the coast of Asia suggests that biogenic emissions (calculated as a residual after subtracting other sources from the total estimated global ethanol source) are the largest contributors to ethanol abundances, followed by roughly equal contributions from anthropogenic emissions, biomass burning, and atmospheric production (Singh et al., 2004) (Table 1). In contrast, measurements off the coast of New England in July-August 2002 suggest that the ethanol source is largely anthropogenic with a small biogenic source but no discernible secondary source from atmospheric production (de Gouw et al., 2005). These studies highlight regional variations in ethanol sources, making it difficult to determine the global budget solely from the limited set of available observations. Here we apply a global model in an attempt to synthesize and interpret available observations of ethanol from several regions around the globe.

\section{Model and experiments}

We simulate the global atmospheric distribution of ethanol accounting for its estimated sources and sinks in the MOZART-4 chemical transport model (Emmons et al., 2010). Meteorological fields are from the NCEP Global Forecast System (GFS) for July 2003 to December 2004 at a horizontal resolution of $1.9^{\circ}$ latitude $\times 1.9^{\circ}$ longitude with 64 vertical levels; the first six months of the simulations are used for model spin-up and results are analyzed for the final year. A previous simulation using MOZART-4 with a similar configuration was evaluated with aircraft measurements of ozone and its precursors over the northeastern United States in summer 2004 during the Intercontinental Chemical Transport Experiment - North America (INTEX-NA) and was found to resolve boundary layer ventilation as indicated by the model skill at capturing the observed campaign-mean vertical profiles of carbon monoxide, ethane, and other hydrocarbons (Horowitz et al., 2007).

\subsection{Ethanol sources}

In the BASE simulation, we use the POET (Precursors of Ozone and their Effects in the Troposphere) emission inventory for the year 2000, which includes anthropogenic ethanol emissions of $5.0 \mathrm{Tg} \mathrm{yr}^{-1}$ of which $3.2 \mathrm{Tg} \mathrm{yr}^{-1}$ come from industrial sources and $1.8 \mathrm{Tg} \mathrm{yr}^{-1}$ from biofuels (biomassderived fuels) globally (Olivier et al., 2003). Our initial assessment of the geographical distribution of these ethanol emissions indicated that they did not match the regional ethanol production statistics provided in the Renewable fuels Association Ethanol Industry Outlook (2006). For lack of detailed information on how ethanol emissions were compiled by Olivier et al. (2003), we updated the spatial distribution of these emission estimates by first dividing the world into 10 regions and calculating the mean ethanol production in each region based on the country-wise ethanol production statistics provided in the Renewable fuels Association Ethanol Industry Outlook (2006). We then redistributed the 


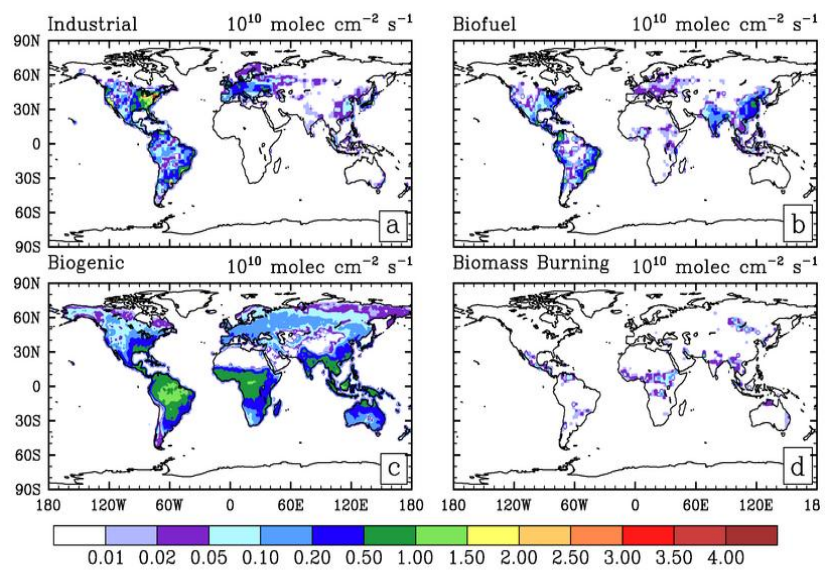

Fig. 1. Annual average emissions (in units of $10^{10}$ molecules $\mathrm{cm}^{-2} \mathrm{~s}^{-1}$ ) of ethanol from different sources: (a) industrial, (b) biofuels, (c) biogenic, and (d) biomass burning.

POET emissions for each region on the basis of the regional ethanol production statistics keeping the same global total as in the POET emissions (Fig. 1a and b).

Laboratory and field measurements suggest that ethanol is produced from fermentative processes in trees in response to a number of environmental stresses including flooding, drought, or high levels of pollutant trace gases (for example, ozone or sulfur dioxide) (Kimmerer and Kozlowski, 1982; MacDonald and Kimmerer, 1987). For example, laboratory measurements show enhanced ethanol emissions from flooded trees and grasses over those from non-flooded plants (Holzinger et al., 2000). Field measurements conducted in the Sierra Nevada Mountains show that high levels of ethanol are emitted from ponderosa pine trees (Schade and Goldstein, 2001), with elevated emissions after high ozone deposition fluxes (Schade and Goldstein, 2002). Measurements also show that ambient temperature and moisture strongly influence ethanol emissions from ponderosa pine trees (Schade and Goldstein, 2001, 2002). However, since field measurements are scarce, it is not clear whether all green plants emit ethanol by the same mechanism. Furthermore, lack of widespread field measurements makes it difficult to develop models to estimate biogenic ethanol emissions on a global scale.

Here, we simulate biogenic ethanol emissions using an approach that combines the procedures of Guenther et al. (2000) and Guenther et al. (2006) with observations reported by Schade and Goldstein $(2001,2002)$. Our emission estimate is meant to provide a first guess about the magnitude, spatial distribution, and the potential importance of biogenic ethanol emissions on a global scale. Emissions are calculated as

Emission $=E F \cdot \gamma_{T} \cdot \gamma_{\mathrm{LAI}}$,

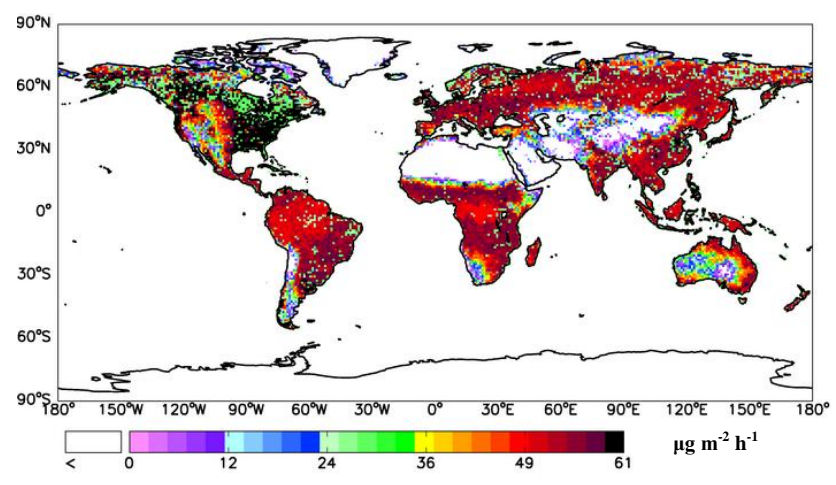

Fig. 2. Global biogenic emission factors for ethanol at $1^{\circ}$ latitude $\times 1^{\circ}$ longitude resolution in units of $\mu \mathrm{g} \mathrm{m}^{-2} \mathrm{~h}^{-1}$.

where $E F$ is the vegetation-specific emission factor $\left(\mathrm{mg} \mathrm{m}^{-2} \mathrm{~h}^{-1}\right)$ for ethanol, $\gamma_{T}$ is the temperature dependence for ethanol emission, and $\gamma_{\mathrm{LAI}}$ is the dependence of the emissions on leaf area index. The emission factors (Fig. 2) for ethanol are primarily based on the recommendations of Guenther et al. (2000) except that emissions from coniferous tress are based on measurements at the ponderosa pine plantation in the Sierra Nevada Mountains of California (Schade and Goldstein, 2001, 2002). The minimal set of measurements results in emission factors that are highly uncertain, estimated at a factor of 3 . The temperature dependence for ethanol emissions is given by $\gamma_{T}=\exp \left[\beta *\left(T_{\text {air }}-303\right)\right]$, where $\beta=0.13$ (Schade and Goldstein, 2001) and $T_{\text {air }}$ is air temperature. The dependence of emissions on leaf area index is given by $\gamma_{\mathrm{LAI}}=0.49 \cdot \mathrm{LAI}_{c} /\left[\left(1+0.2 \cdot \mathrm{LAI}_{c}^{2}\right)^{0.5}\right]($ Guenther et al., 2006) where $\mathrm{LAI}_{c}$ is the monthly mean leaf area index. The dependence of ethanol emissions on root flooding or plant stress is not considered here. With the availability of more information, the calculation of biogenic ethanol emissions has recently been revised to include the dependence on light and root flooding in MEGANv2.1 (Millet et al., 2010). We calculate monthly mean emissions offline using average emission factors (Fig. 2), leaf area index derived from MODIS satellite measurements for 2003, and hourly air temperatures from the model surface level. We then apply these in the model to obtain an annual global biogenic source of $9.2 \mathrm{Tg} \mathrm{yr}^{-1}$ shown in Fig. 1c. We expect the lack of daily variability in biogenic emissions in the model to lead to overestimates on cool days and underestimate on warm days. However, this lack of daily variation is unlikely to account for the large model biases discussed in Sect. 3.

Biomass burning ethanol emissions are obtained by applying ethanol emission factors relative to carbon monoxide (CO) for combustion of different types of biomass (Andreae and Merlet, 2001) to CO emissions from the POET inventory except over North America during summer 2004 where we use a daily emission inventory (Turquety et al., 2007). The emission factors range from $1.7-1.9 \times 10^{-4} \mathrm{~g} / \mathrm{g}$ and the 
resulting global total biomass burning ethanol emission is $0.5 \mathrm{Tg} \mathrm{yr}^{-1}$ (Fig. 1d). Significant uncertainties exist in the emission factors of ethanol as they have been extrapolated from those of CO (Andreae and Merlet, 2001). We include in our BASE simulation tracers of ethanol tagged by each of the four emissions sources (industrial, biofuel, biogenic and biomass burning).

Atmospheric production of ethanol occurs via reactions of the ethyl peroxy radical $\left(\mathrm{C}_{2} \mathrm{H}_{5} \mathrm{O}_{2}\right.$; mainly produced from oxidation of ethane by $\mathrm{OH}$ ) with other organic peroxy radicals under relatively low $\mathrm{NO}_{\mathrm{x}}\left(=\mathrm{NO}+\mathrm{NO}_{2}\right)$ conditions. Previous work estimated this secondary source of ethanol by scaling the global atmospheric source of methanol based on the atmospheric abundances and lifetimes of methane and ethane, precursors to methanol and ethanol, respectively (Singh et al., 2004). We improve upon this earlier methodology by explicitly simulating the atmospheric chemistry of ethanol including the self-reaction of $\mathrm{C}_{2} \mathrm{H}_{5} \mathrm{O}_{2}$ (Reaction R1) and its reaction with the most abundant organic peroxy radical, $\mathrm{CH}_{3} \mathrm{O}_{2}$ (Reaction R2):

$$
\begin{aligned}
& \mathrm{C}_{2} \mathrm{H}_{5} \mathrm{O}_{2}+\mathrm{C}_{2} \mathrm{H}_{5} \mathrm{O}_{2} \\
& \rightarrow 1.6 \mathrm{CH}_{3} \mathrm{CHO}+1.2 \mathrm{HO}_{2}+0.4 \mathrm{C}_{2} \mathrm{H}_{5} \mathrm{OH}
\end{aligned}
$$

$$
\begin{aligned}
& \mathrm{C}_{2} \mathrm{H}_{5} \mathrm{O}_{2}+\mathrm{CH}_{3} \mathrm{O}_{2} \\
& \rightarrow 0.7 \mathrm{CH}_{2} \mathrm{O}+0.8 \mathrm{CH}_{3} \mathrm{CHO}+\mathrm{HO}_{2}+0.3 \mathrm{CH}_{3} \mathrm{OH} \\
& +0.2 \mathrm{C}_{2} \mathrm{H}_{5} \mathrm{OH}
\end{aligned}
$$

We use the recommended kinetic data in the literature for (R1) (Sander et al., 2006) and (R2) (Villenave and Lesclaux, 1996) and the ethanol yields are as suggested by Madronich and Calvert (1990). About $99 \%$ of the atmospheric source of ethanol in the model is from reaction (R2), which primarily occurs in the lower (600 hPa to surface) tropical marine troposphere. Together, these reactions provide a secondary ethanol source of $0.056 \mathrm{Tg} \mathrm{yr}^{-1}$ in the model, accounting for less than $1 \%$ of the total source of ethanol.

\subsection{Ethanol sinks}

Atmospheric sinks for ethanol in the model include gasphase oxidation by the hydroxyl radical $(\mathrm{OH})$, dry deposition, and wet scavenging. We apply the $\mathrm{OH}$-oxidation reaction rate constant $\left.k=6.9 \times 10^{-12} \mathrm{exp}-230 / T\right]$ recommended by Sander et al. (2002) with an uncertainty of $\sim 20 \%$ at a temperature of $298 \mathrm{~K}$. Gas phase oxidation accounts for about $65 \%$ of the atmospheric loss of ethanol (Table 1). Because of its capacity to form strong hydrogen bonds, ethanol is highly soluble in water and can therefore be removed by precipitation. Wet deposition is calculated using the temperaturedependent effective Henry's Law coefficient which is taken to be $H=(1.94 \pm 0.13) \times 10^{2} \exp [(6274 \pm 241.6)(1 / T-1 / 298)]$ based on a compilation of measurements of the gas-liquid partition coefficient for ethanol (Warneck, 2006). In the absence of information on the dry deposition velocity of ethanol, we assume its deposition velocity is the same as that for methyl hydroperoxide (global mean velocity over land of $0.13 \mathrm{~cm} \mathrm{~s}^{-1}$ ) and because its water-solubility is similar to that of methanol, we apply a deposition velocity over oceans equal to that of methanol (global mean velocity of $0.08 \mathrm{~cm}$ $\mathrm{s}^{-1}$ ) (Jacob et al., 2005). Dry deposition and wet scavenging account for $25 \%$ and $10 \%$ of the total global loss, respectively.

\section{Results and discussion}

The BASE simulation yields a global mean ethanol burden of $0.1 \mathrm{Tg}$ and a mean atmospheric lifetime of 2.8 days (Table 1$)$. The annual mean boundary layer $(0-2 \mathrm{~km})$ concentration of ethanol in the model over continents is $71 \mathrm{pptv}$ while that over oceans is $11 \mathrm{pptv}$. Our estimate of the global source of ethanol $\left(15 \mathrm{Tg} \mathrm{yr}^{-1}\right)$ is within the previously estimated range $\left(8-17 \mathrm{Tg} \mathrm{yr}^{-1}\right)$ (Singh et al., 2004). Similar to the previous source estimate, biogenic emissions account for the largest fraction of emissions (63\%) in our inventory; however, we estimate a larger contribution from anthropogenic sources including biofuels $(33 \%)$, and smaller contributions from biomass burning (3\%) and atmospheric production $(<1 \%)$ (Table 1). High ethanol concentrations (200-1600 pptv) are simulated (Fig. 3) over regions with large emissions from vegetation (North and South America, Africa) and from anthropogenic sources (North and South America, Europe, Asia). Concentrations typically decrease by a factor of 5-10 from the surface to mid-troposphere, reflecting the importance of surface sources and the short lifetime of ethanol. The simulated ethanol concentration over the remote oceans is less than $10 \mathrm{pptv}$ with little vertical gradient.

Large-scale aircraft campaigns and field experiments conducted over the last decade have contributed to our understanding of the atmospheric distribution of OVOCs, including ethanol. Typical urban mean ethanol concentrations of 2-3 ppbv (Pittsburgh and Granite Bay) (Millet et al., 2005) are 1-2 orders of magnitude higher than the $0.05-0.1 \mathrm{ppb}$ measured in rural (Chebogue Point and Trinidad Head) (Millet et al., 2004, 2006) and remote regions (remote Pacific Ocean) (Singh et al., 2001). To assess the degree of consistency between atmospheric measurements and our understanding of the budget of ethanol, we compare the ethanol concentrations from our BASE simulation with aircraft and surface measurements. The details of aircraft campaigns and surface observations used in this study are provided in Table 2 . These ethanol measurements are mainly limited to the North American region, with the exception of two aircraft campaigns. We focus mostly on large-scale aircraft measurements as our global-scale model is not expected to resolve 
Table 2. Aircraft and surface measurements of ethanol used for comparison with model simulated ethanol concentrations. Mean and standard deviations of observed ethanol mixing ratios with those simulated in the BASE run are given for comparison.

\begin{tabular}{|c|c|c|c|c|c|}
\hline Study & Time & Location & $\begin{array}{l}\text { Mean Observed Mix- } \\
\text { ing Ratio (ppbv) }\end{array}$ & BASE (ppbv) & Reference \\
\hline \multicolumn{6}{|l|}{ Aircraft Campaigns } \\
\hline PEM-Tropics B ${ }^{a}$ & Mar-Apr 1999 & South Pacific & $0.05 \pm 0.03$ & $0.01 \pm 0.02$ & Singh et al. (2001) \\
\hline TRACE-P ${ }^{\mathrm{a}}$ & Feb-Apr 2001 & North Pacific & $0.14 \pm 0.24$ & $0.03 \pm 0.03$ & Singh et al. (2004) \\
\hline INTEX-NA $^{a}$ & Jul-Aug 2004 & US, Canada & $0.40 \pm 0.70$ & $0.20 \pm 0.12$ & Singh et al. (2006) \\
\hline INTEX-B $^{a}$ & Mar 2006 & US, Mexico & $0.30 \pm 0.30$ & $0.10 \pm 0.07$ & Singh et al. (2009) \\
\hline \multicolumn{6}{|l|}{ Surface stations } \\
\hline Granite Bay, CA & Jul-Sep 2001 & US & $1.90 \pm 0.91$ & $1.04 \pm 0.23$ & Murphy et al. (2007) \\
\hline Trinidad Head, CA & Apr-May 2002 & US & $0.14 \pm 0.08$ & $0.20 \pm 0.08$ & Millet et al. (2004) \\
\hline \multirow[t]{2}{*}{ Pittsburgh, PA } & Jan-Feb, 2002 & US & $1.43 \pm 1.25$ & $1.61 \pm 0.60$ & Millet et al. (2005) \\
\hline & Jul-Aug 2002 & & $3.02 \pm 2.90$ & $1.25 \pm 0.34$ & Millet et al. (2005) \\
\hline $\begin{array}{l}\text { Chebogue Point, Nova Scotia } \\
\text { Ship Cruises }\end{array}$ & Jul-Aug 2004 & Canada & $0.15 \pm 0.07$ & $0.25 \pm 0.09$ & Millet et al. (2006) \\
\hline NEAQS-2K2 & Jul-Aug 2002 & North Atlantic & $0.23 \pm 0.20$ & $0.47 \pm 0.33$ & de Gouw et al. (2005) \\
\hline NEAQS-2K4 & Jul-Aug 2004 & North Atlantic & $0.32 \pm 0.43$ & $0.47 \pm 0.33$ & Warneke et al. (2005) \\
\hline
\end{tabular}

${ }^{\text {a }}$ Mean observation from surface to $2 \mathrm{~km}$, averaged on to the model grid.

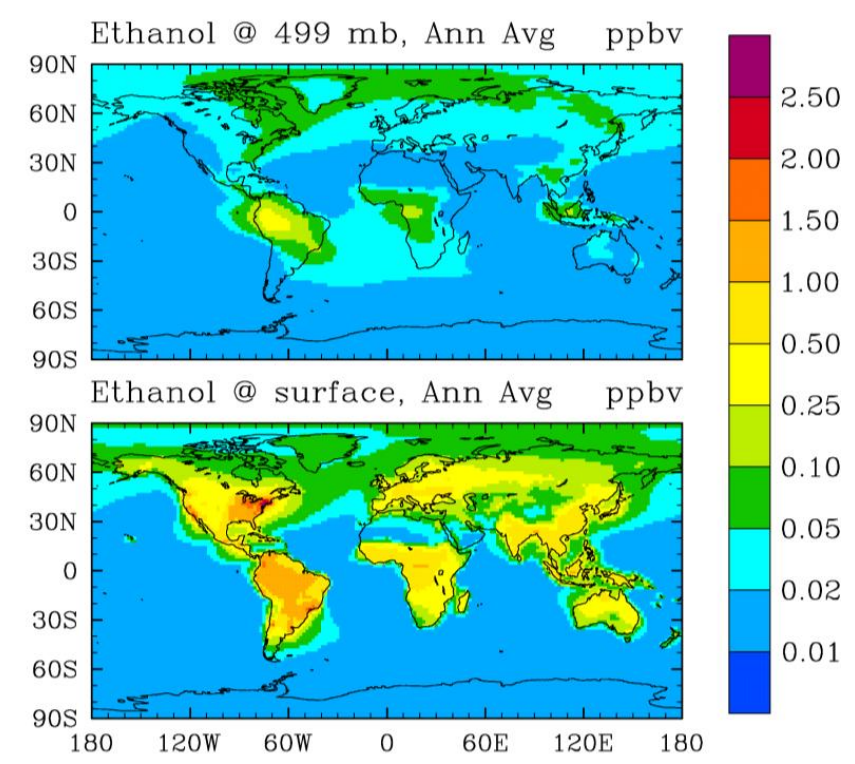

Fig. 3. Simulated annual mean concentration of ethanol near the surface and at $500 \mathrm{mb}$.

urban airsheds and these provide greater spatial coverage, sampling downwind of Asia and over the remote southern Pacific in addition to North America. The BASE simulation consistently overestimates the ship measurements over the North Atlantic (Fig. 4); our tracers tagged by ethanol sources indicate that industrial emissions are the primary source of ethanol $(\sim 70 \%)$ off the coast of the northeastern US (Fig. 5), suggesting that surface industrial emissions in the model are probably too high upwind of the mea-

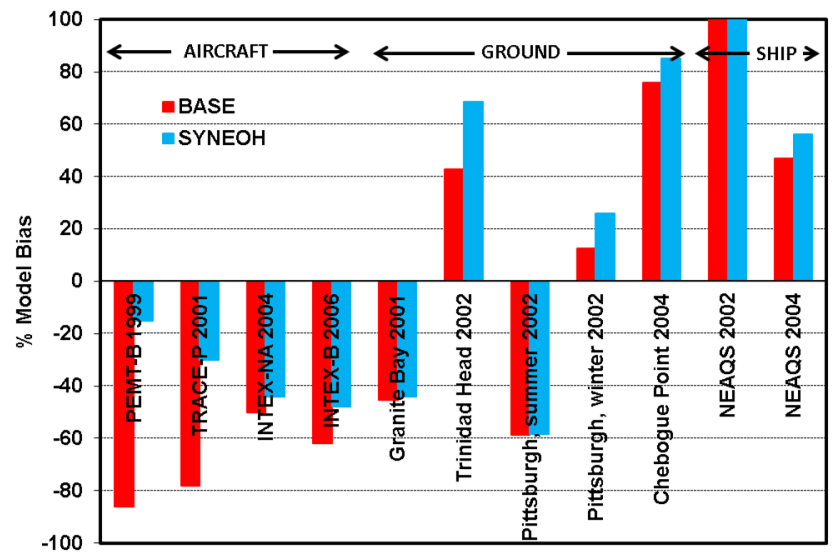

Fig. 4. Comparison of simulated ethanol concentrations with observations from four aircraft field campaigns (below $2 \mathrm{~km}$; PEMTropics B over the South Pacific in March-April 1999, TRACE-P downwind of Asia over the North Pacific in February-April 2001, INTEX-NA over the eastern United States in July-August 2004 and INTEX-B over Mexico City and the Gulf of Mexico in March 2006), four site-specific ground measurements (Granite Bay, California in July-September 2001, Trinidad Head, California in AprilMay 2002, Pittsburgh, Pennsylvania in July-August and JanuaryFebruary 2002, and Chebogue Point, Nova Scotia in July-August 2004), and two ship-based surface measurements (NEAQS along the northeastern US coast in July-August 2002 and 2004). Observations are averaged onto the horizontal model grid with a resolution of $1.9^{\circ} \times 1.9^{\circ}$. Surface model concentrations are used for comparison with ship-based and ground measurements, while model concentrations are averaged vertically below $2 \mathrm{~km}$ for comparison with aircraft measurements. 


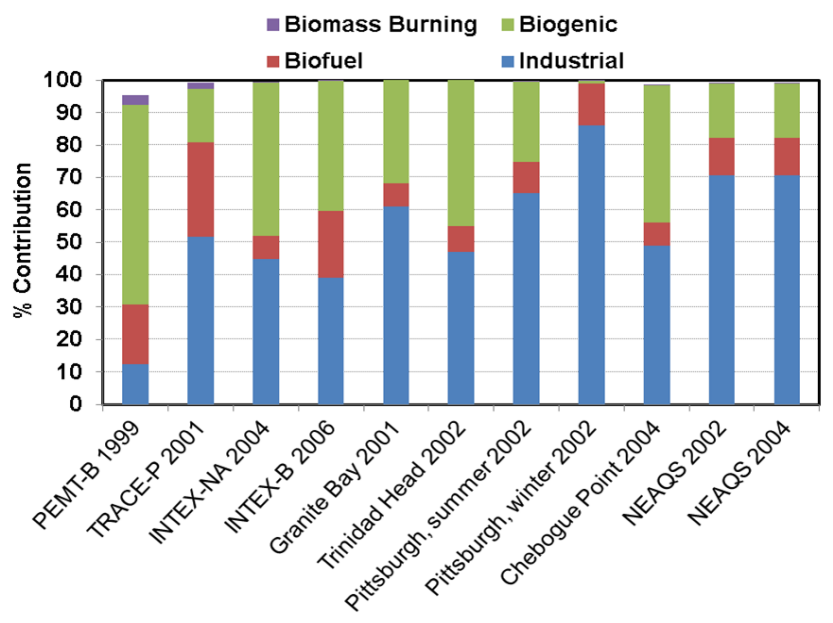

Fig. 5. Percent contribution from individual ethanol sources in the BASE simulation for each observational campaign/site shown in Fig. 4.

surement cruise track. The BASE simulation also overestimates surface ethanol concentrations measured at coastal sites (Trinidad Head, Chebogue Point) while underestimating values measured in areas influenced by urban emissions, except in Pittsburgh during winter. Finally, the simulation consistently underestimates aircraft observations in the boundary layer and this relative underestimate worsens moving from North America to remote oceanic regions (off the coast of Asia and over the South Pacific ocean). One could interpret the model underestimate of aircraft measurements over North America and an overestimate of ship observations along the northeastern US coast (described above) as a disparity between the two sets of observations. However, it is possible to reconcile these comparisons given the different regional coverage of measurements particularly if different sources contribute to the observed ethanol concentrations. The aircraft flight tracks cover a much larger area $\left(60^{\circ}\right.$ to $130^{\circ}$ West and $24^{\circ}$ to $52^{\circ}$ North) than the ship tracks ( $67^{\circ}$ to $75^{\circ}$ West and $41^{\circ}$ to $44^{\circ}$ North). The tagged tracers in Fig. 5 indicate that industrial and biogenic sources contribute equally to the ethanol concentrations sampled by the aircraft in the lower troposphere (below $2 \mathrm{~km}$ ) over North America, while industrial sources are the primary source of ethanol measured off the northeastern US coast in agreement with the findings of de Gouw et al. (2005).

We compare the mean vertical distribution of ethanol from the BASE simulation with observed values from the four aircraft campaigns (Fig. 6). Observations and simulated concentrations are averaged in $1 \mathrm{~km}$ bins onto the horizontal model grid for the ensemble of the data. Observed mean ethanol concentrations decrease by more than a factor of three near the surface $(0.37-0.45 \mathrm{pbbv})$ to $5 \mathrm{~km}$ (0.05-0.11 ppbv) over the eastern United States (INTEX-NA campaign), and over Mexico City and the Gulf of Mex- ico (INTEX-B campaign). This decrease is not uniform as higher values are observed at altitudes above $5 \mathrm{~km}$, particularly over Mexico City and the Gulf of Mexico because of strong convective influence (Fast et al. 2007). Mean ethanol mixing ratios measured downwind of Asia (TRACE-P mission) also decrease with altitude albeit with a small vertical gradient. A small reversed vertical gradient in mean ethanol concentrations is observed over the remote south Pacific region (PEM-Tropics B mission) with higher values at altitudes above $3 \mathrm{~km}(0.6-0.1 \mathrm{ppbv})$ than those near the surface (0.05 ppbv). The BASE simulation underestimates observed ethanol at all altitudes over North America and downwind of Asia by more than $50 \%$ and this underestimate worsens to over $100 \%$ over the remote southern Pacific. The BASE simulation also underestimates ethanol concentrations measured at the high alpine site Jungfraujoch (Switzerland) (Legreid et al., 2008) by over $100 \%$ (data not shown). As noted in the previous section, MOZART-4 adequately resolves boundary layer ventilation, therefore, this underestimate is unlikely to reflect a problem with the model vertical mixing. A possible explanation of the model underestimate of ethanol in the boundary layer (Fig 4) could be a model overestimate of $\mathrm{OH}$ radical, however, model $\mathrm{OH}$ is somewhat lower than the $\mathrm{OH}$ climatology from Spivakovsky et al. (2000), consistent with the findings of Emmons et al. (2010). Given the short lifetime of ethanol, additional continental emissions fail to eliminate the strong underestimate over the remote regions. The lack of an observed vertical gradient in ethanol concentrations over the ocean also precludes an oceanic source; reducing the oceanic sink by decreasing the deposition velocity over oceans $(0.28$ to $0.08 \mathrm{~cm} / \mathrm{s})$ does not explain the discrepancy. This inability to simulate high observed mixing ratios in the free troposphere has been shown to occur for acetaldehyde in another global chemical transport model (Millet et al., 2010), indicating a general inconsistency between the observations and our understanding of the budget of short-lived volatile organic compounds.

Current chemistry-transport models are unable to correctly simulate the relatively high OVOC concentrations, particularly aldehydes and alcohols, observed over remote oceanic regions (Singh et al., 2001; Lewis et al., 2005). While measurements of OVOCs under clean-air conditions in the remote free troposphere are challenging and could be impacted by artifacts (Apel et al., 2003, Northway et al., 2004), it has been hypothesized that a large diffuse source of OVOCs exists in remote regions that is presently missing in the models (Singh et al., 2001). A potential source is the presence of other hydrocarbons that can oxidize to form OVOCs (Singh et al., 2001; Lewis et al., 2005). We conduct an additional MOZART-4 simulation, SYNEOH, with a uniform source of 10 pptv day ${ }^{-1}$ ethanol distributed throughout the troposphere (29.3 $\mathrm{Tg} \mathrm{yr}^{-1}$ ) in an attempt to constrain the magnitude of secondary production that would be necessary to match the observations in remote regions. The total source of ethanol in the SYNEOH simulation is three times that in the BASE 

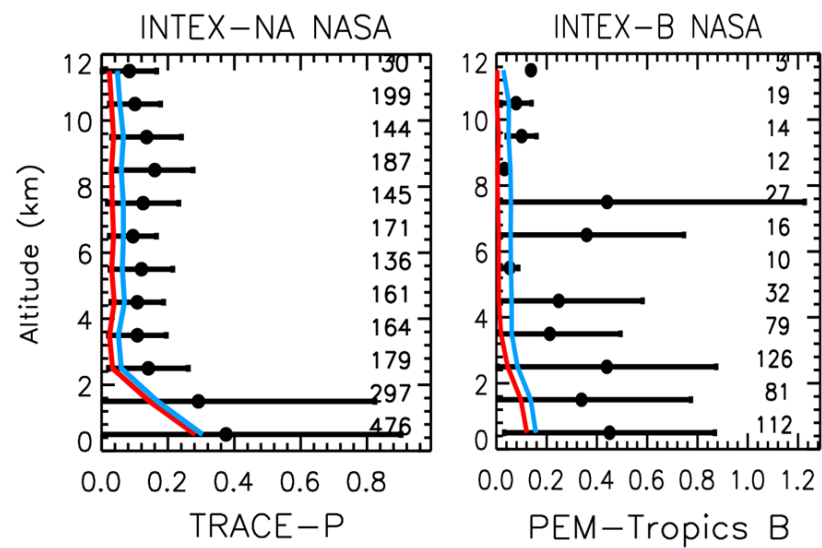

$\begin{array}{llllllll}0.0 & 0.2 & 0.4 & 0.6 & 0.8 & 1.0 & 1.2\end{array}$ PEM-Tropics B

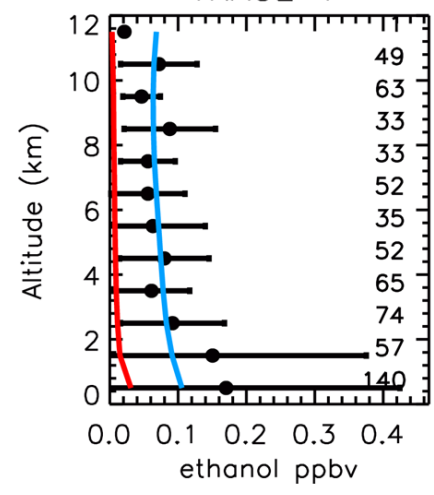

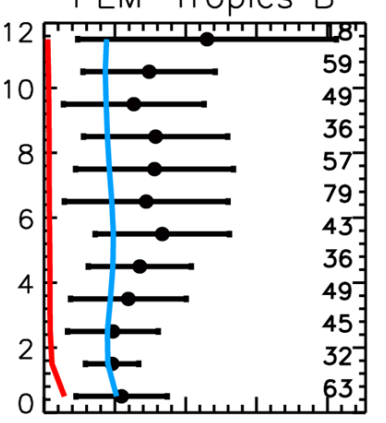

0.000 .050 .100 .150 .20 ethanol ppbv

BASE

SYNEOH

Fig. 6. Mean simulated and observed vertical profiles of ethanol from four aircraft field campaigns (PEM-Tropics B over the South Pacific in March-April 1999, TRACE-P downwind of Asia over the North Pacific in February-April 2001, INTEX-NA over the eastern United States in July-August 2004 and INTEX-B over Mexico City and the Gulf of Mexico in March 2006; black, standard deviations in horizontal lines). Observations and modeled values are averaged in $1 \mathrm{~km}$ bins onto the horizontal model grid. Note the different $\mathrm{x}$ axis scales in each panel.

simulation, while the burden is increased by a factor of six (Table 1). Additional ethanol at higher altitudes where the oxidative loss is slow leads to an increased globally averaged ethanol lifetime (a factor of two higher than that in the BASE simulation). The SYNEOH simulation does not eliminate the disagreement with the North American ship and ground measurements but improves the large mismatch with aircraft measurements, to a $-15 \%$ bias over the remote southern $\mathrm{Pa}-$ cific, and a $-25 \%$ bias downwind of Asia (Fig. 4). Likewise, the vertical distribution of ethanol in SYNEOH agrees better with those observed over the remote southern Pacific and downwind of Asia (Fig. 6). This could indicate that direct emission of ethanol is the dominant source of ethanol over populated continental areas, while secondary production is the major source in remote regions where $\mathrm{NO}_{\mathrm{x}}$ is sufficiently low to allow ethanol production.

OVOCs, including propanal $\left(\mathrm{C}_{2} \mathrm{H}_{5} \mathrm{CHO}\right)$ and peroxy propionic nitrate (PPN), are potential precursors of ethanol in the atmosphere. As measured abundances of propanal are approximately an order of magnitude larger than PPN (Singh et al., 2004), we use propanal as an example OVOC to estimate an additional secondary source of ethanol. Propanal oxidizes to produce the propionyl peroxy radical $\left(\mathrm{C}_{2} \mathrm{H}_{5} \mathrm{CO}_{3}\right)$, which can then react with $\mathrm{CH}_{3} \mathrm{O}_{2}$, other organic peroxy radicals, $\mathrm{HO}_{2}$, or $\mathrm{NO}$ depending on the relative concentration of these species. Reaction of $\mathrm{C}_{2} \mathrm{H}_{5} \mathrm{CO}_{3}$ with $\mathrm{CH}_{3} \mathrm{O}_{2}$ produces the ethyl peroxy radical that can then react to produce ethanol (via Reaction R2).

$$
\begin{aligned}
& \mathrm{C}_{2} \mathrm{H}_{5} \mathrm{CHO}+\mathrm{OH}+\left(\mathrm{O}_{2}\right) \rightarrow \mathrm{C}_{2} \mathrm{H}_{5} \mathrm{CO}_{3}+\mathrm{H}_{2} \mathrm{O} \\
& \mathrm{C}_{2} \mathrm{H}_{5} \mathrm{CO}_{3}+\mathrm{CH}_{3} \mathrm{O}_{2} \rightarrow 0.7 \mathrm{C}_{2} \mathrm{H}_{5} \mathrm{O}_{2}+ \\
& 0.3 \mathrm{C}_{2} \mathrm{H}_{5} \mathrm{COOH}+0.7 \mathrm{CO}_{2}+0.7 \mathrm{HO}_{2}+\mathrm{O}_{2}+\mathrm{CH}_{2} \mathrm{O} \\
& \mathrm{C}_{2} \mathrm{H}_{5} \mathrm{CO}_{3}+\mathrm{HO}_{2} \rightarrow 0.71 \mathrm{C}_{2} \mathrm{H}_{5} \mathrm{COOOH} \rightarrow \\
& 0.29 \mathrm{C}_{2} \mathrm{H}_{5} \mathrm{COOH}+0.71 \mathrm{O}_{2}+0.29 \mathrm{O}_{3} \\
& \mathrm{C}_{2} \mathrm{H}_{5} \mathrm{CO}_{3}+\mathrm{NO}\left(+\mathrm{O}_{2}\right) \rightarrow \mathrm{C}_{2} \mathrm{H}_{5} \mathrm{O}_{2}+\mathrm{NO}_{2}+\mathrm{CO}_{2} \\
& \mathrm{C}_{2} \mathrm{H}_{5} \mathrm{O}_{2}+\mathrm{NO} \rightarrow \mathrm{CH}_{3} \mathrm{CHO}_{+} \mathrm{HO}_{2}+\mathrm{NO}_{2} \\
& \mathrm{C}_{2} \mathrm{H}_{5} \mathrm{O}_{2}+\mathrm{HO} \rightarrow \mathrm{C}_{2} \mathrm{H}_{5} \mathrm{OOH}+\mathrm{O}_{2}
\end{aligned}
$$

The ethanol production rate from the above sequence of chemical reactions is given by $P\left(\mathrm{C}_{2} \mathrm{H}_{5} \mathrm{OH}\right)=0.2 \cdot k_{2}$ $\left[\mathrm{C}_{2} \mathrm{H}_{5} \mathrm{O}_{2}\right]\left[\mathrm{CH}_{3} \mathrm{O}_{2}\right]$. The $\mathrm{C}_{2} \mathrm{H}_{5} \mathrm{OH}$ production from the self-reaction is two orders of magnitude smaller and therefore negligible. Since $\mathrm{C}_{2} \mathrm{H}_{5} \mathrm{O}_{2}$ and $\mathrm{C}_{2} \mathrm{H}_{5} \mathrm{CO}_{3}$ are shortlived radicals, we assume their concentrations to be at steady state. The ethanol production rate is then given by $P\left(\mathrm{C}_{2} \mathrm{H}_{5} \mathrm{OH}\right)=0.2 \times k_{3} \times f \times\left[\mathrm{C}_{2} \mathrm{H}_{5} \mathrm{CHO}\right][\mathrm{OH}]$, where

$$
\begin{aligned}
& f=\frac{k_{2}\left[\mathrm{CH}_{3} \mathrm{O}_{2}\right]}{k_{4}\left[\mathrm{CH}_{3} \mathrm{O}_{2}\right]+k_{5}\left[\mathrm{HO}_{2}\right]+k_{6}[\mathrm{NO}]} \\
& \times \frac{0.7 k_{4}\left[\mathrm{CH}_{3} \mathrm{O}_{2}\right]+k_{6}[\mathrm{NO}]}{k_{2}\left[\mathrm{CH}_{3} \mathrm{O}_{2}\right]+k_{7}[\mathrm{NO}]+k_{8}\left[\mathrm{HO}_{2}\right]}
\end{aligned}
$$

We obtain the values of rate constants $k_{3}, k_{4}, k_{5}$, and $k_{6}$ from the Master Chemical Mechanism (http://mcm.leeds.ac. uk/MCM), and $k_{2}, k_{7}$, and $k_{8}$ from Sander et al. (2006). Applying the rate constants at $298 \mathrm{~K}$ for average atmospheric conditions with $\left[\mathrm{CH}_{3} \mathrm{O}_{2}\right]=\left[\mathrm{HO}_{2}\right]=1 \times 10^{8}$ molecules $\mathrm{cm}^{-3}$ and $[\mathrm{NO}]=2.5 \times 10^{8}$ molecules $\mathrm{cm}^{-3}$ leads to an estimated $f=0.005$. Assuming a mean $\mathrm{OH}$ concentration of $1.0 \times 10^{6}$ molecules $\mathrm{cm}^{-3}$ (Spivakovsky et al., 2000), mean background tropospheric $\mathrm{C}_{2} \mathrm{H}_{5} \mathrm{CHO}$ concentration of $9.8 \times 10^{8}$ molecules $\mathrm{cm}^{-3}$ (measured off the coast of Asia), and $k_{3}=1.9 \times 10^{-11}$ at $298 \mathrm{~K}$, yields an estimated ethanol 
source of up to $0.1 \mathrm{pptv}^{\mathrm{day}}{ }^{-1}$ equivalent to a global source of approximately $0.3 \mathrm{Tg} \mathrm{yr}^{-1}$. Additionally, propanal can photolyze and react with $\mathrm{NO}_{3}$ to provide another source of ethyl peroxy radical which can then produce ethanol via Reaction(R2):

$$
\begin{aligned}
& \mathrm{C}_{2} \mathrm{H}_{5} \mathrm{CHO}+\mathrm{h} v \rightarrow \mathrm{C}_{2} \mathrm{H}_{5} \mathrm{O}_{2}+\mathrm{HO}_{2}+\mathrm{CO} \\
& \mathrm{C}_{2} \mathrm{H}_{5} \mathrm{CHO}+\mathrm{NO}_{3} \rightarrow \mathrm{C}_{2} \mathrm{H}_{5} \mathrm{CO}_{3}+\mathrm{HNO}_{3} \\
& \mathrm{C}_{2} \mathrm{H}_{5} \mathrm{CO}_{3}+\mathrm{NO}_{3} \rightarrow \mathrm{C}_{2} \mathrm{H}_{5} \mathrm{O}_{2}+\mathrm{NO}_{2}
\end{aligned}
$$

Including these reactions in the above mechanism adds up to $0.1 \mathrm{pptv}^{\mathrm{day}}{ }^{-1}$ to the ethanol source from propanal. We note, however, that our calculation depends on the observed value of propanal, which is difficult to measure accurately at low free tropospheric concentrations.

Thus, secondary atmospheric production of ethanol from measured precursor OVOCs is unlikely to explain the ethanol concentrations observed in remote environments. Further research is therefore needed to fully explore the missing precursors or sources of atmospheric ethanol.

\section{Conclusions}

Ethanol plays an important role in global tropospheric chemistry; oxidation of ethanol is an important source of acetaldehyde, a highly toxic pollutant and an OVOC for which the budget remains poorly quantified (Singh et al., 2001, 2004). Better constraints on the present-day ethanol budget are essential for evaluating the impacts of future increases in the use of biomass-derived ethanol. We have used available observations in conjunction with a global CTM to examine the global budget of ethanol. In comparison with the previously estimated range of $8-17 \mathrm{Tg} \mathrm{yr}^{-1}$ (Singh et al., 2004) for the global source of ethanol, our best estimate is $15.0 \mathrm{Tg} \mathrm{yr}^{-1}$ including $5.0 \mathrm{Tg} \mathrm{yr}^{-1}$ from industrial sources and biofuels, $9.2 \mathrm{Tg} \mathrm{yr}^{-1}$ from terrestrial plants, $\sim 0.5 \mathrm{Tg} \mathrm{yr}^{-1}$ from biomass burning, and $0.05 \mathrm{Tg} \mathrm{yr}^{-1}$ from atmospheric in-situ production. Our model yields a global mean atmospheric lifetime for ethanol of 2.8 days, with $65 \%$ of the total loss resulting from gas-phase oxidation by $\mathrm{OH}, 25 \%$ from dry deposition to land, and 10\% from wet deposition. Our analysis suggests that while surface emissions of ethanol are important for continental areas, neither surface sources nor atmospheric production from measured precursor hydrocarbons explain the ethanol concentrations measured in remote oceanic regions where simulated ethanol concentration is an order of magnitude too low. Further work is needed to understand the large ethanol abundance over remote oceanic regions and to better constrain the global ethanol budget and distribution. Specifically, better and wider spatial sampling of atmospheric ethanol and its precursors is needed. Observation-based estimates of the ethanol deposition velocity are also needed for improved modeling of atmospheric losses of ethanol. Additional direct measurements of biogenic ethanol fluxes from a variety of ecosystems will improve confidence in the estimated biogenic source.

Acknowledgements. We thank Michael Oppenheimer for helpful discussions and Erin Czech for providing INTEX-B data. We are grateful to Hiram Levy and Song-Miao Fan for reviewing an earlier version of this manuscript. V. Naik was supported by the Carbon Mitigation Initiative (CMI) of the Princeton Environmental Institute at Princeton University (http://cmi.princeton.edu) which is sponsored by BP and Ford, and the visiting scientist program in Atmospheric and Oceanic Sciences at Princeton and NOAA/GFDL.

Edited by: M. Kanakidou

\section{References}

Andreae, M. and Merlet, P.: Emissions of trace gases and aerosols from biomass burning, Global Biogeochem. Cycl., 15, 955-966, 2001.

Apel, E. C., Hills, A., Lueb, R., Zindel, S., Eisele, S., and Riemer, D.: A fast-GC/MS system to measure C-2 to C-4 carbonyls and methanol aboard aircraft, J. Geophys. Res., 108, 8794, doi:10.1029/2002JD003199, 2003.

Blando, J. D. and Turpin, B. J.: Secondary organic aerosol formation in cloud and fog droplets: a literature review of plausibility, Atmos. Environ., 34, 1623-1632, 2000.

de Gouw, J. A., Middlebrook, A. M., Warneke, C., Goldan, P. D., Kuster, W. C., Roberts, J. M., Fehsenfeld, F. C., Worsnop, D. R., Canagaratna, M. R., Pszenny, A. A. P., Keene, W. C., Marchewka, M., Bertman, S. B., and Bates, T. S.: Budget of organic carbon in a polluted atmosphere: Results from the New England Air Quality Study in 2002, J. Geophys. Res., 110, D16305, doi:10.1029/2004JD005623, 2005.

Emmons, L. K., Walters, S., Hess, P. G., Lamarque, J.-F., Pfister, G. G., Fillmore, D., Granier, C., Guenther, A., Kinnison, D., Laepple, T., Orlando, J., Tie, X., Tyndall, G., Wiedinmyer, C., Baughcum, S. L., and Kloster, S.: Description and evaluation of the Model for Ozone and Related chemical Tracers, version 4 (MOZART-4), Geosci. Model Dev., 3, 43-67, doi:10.5194/gmd3-43-2010, 2010.

Fast, J. D., de Foy, B., Acevedo Rosas, F., Caetano, E., Carmichael, G., Emmons, L., McKenna, D., Mena, M., Skamarock, W., Tie, X., Coulter, R. L., Barnard, J. C., Wiedinmyer, C., and Madronich, S.: A meteorological overview of the MILAGRO field campaigns, Atmos. Chem. Phys., 7, 2233-2257, doi:10.5194/acp-7-2233-2007, 2007.

Grosjean, E., Grosjean, D., Gunawardena, R., and Rasmussen, R. A.: Ambient concentrations of ethanol and methyl tert-butyl ether in Porto Alegre, Brazil, March 1996-April 1997. Environ. Sci. Technol., 32, 736-742, 1998.

Guenther, A., Geron, C., Pierce, T., Lamb, B., Harley, P., and Fall, R.: Natural emissions of non-methane volatile organic compounds, carbon monoxide, and oxides of nitrogen from North America, Atmos. Environ., 34, 2205-2230, 2000.

Guenther, A., Karl, T., Harley, P., Wiedinmyer, C., Palmer, P. I., and Geron, C.: Estimates of global terrestrial isoprene emissions using MEGAN (Model of Emissions of Gases and Aerosols from 
Nature), Atmos. Chem. Phys., 6, 3181-3210, doi:10.5194/acp-63181-2006, 2006.

Holzinger, R., Sandoval-Soto, L., Rottenberger, S., Crutzen, P. J., and Kesselmeier, J.: Emissions of volatile organic compounds from Quercus ilex L. measured by Proton transfer reaction mass spectroscopy under different environmental conditions, J. Geophys. Res., 105, 20573-20579, 2000.

Horowitz, L. W., Fiore, A. M., Milly, G. P., Cohen, R. C., Perring, A., Wooldridge, P. J., Hess, P. G., Emmons, L. K., and Lamarque, J.-F.: Observational constraints on the chemistry of isoprene nitrates over the eastern United States, J. Geophys. Res., 112, D12S08, doi:10.1029/2006JD007747, 2007.

Jacob, D. J., Field, B. D., Li, Q., Blake, D. R., de Gouw, J., Warneke, C., Hansel, A., Wisthaler, A., and Singh, H. B.: Global budget of methanol: constraints from atmospheric observations, J. Geophys. Res., 110, D08303, doi:10.1029/2004JD005172, 2005.

Jacobson, M. Z: Effects of ethanol (E85) versus gasoline vehicles on cancer and mortality in the United States, Environ. Sci. Technol., 41(11), 4150-4157, doi:10.1021/es062085v, 2007.

Knapp, K. T., Stump, F. D., and Tejada, S. B.: Effect of ethanol fuel on the emissions of vehicles over a wide range of temperatures, J. Air. Waste. Mgmt. Assoc., 48, 646-653, 1998.

Kimmerer, T. W. and Kozlowski, T. T.: Ethylene, ethane, acetaldehyde, and ethanol production by plants under stress, Plant Physiol., 69, 840-847, 1982.

Legreid, G., Folini, D., Staehelin, J., Lööv, J. B., Steinbacher, M., and Reimann, S.: Measurements of organic trace gases including oxygenated volatile organic compounds at the high alpine site Jungfraujoch (Switzerland): Seasonal variation and source allocations, J. Geophys. Res., 113, D05307, doi:10.1029/2007JD008653, 2008.

Lewis, A. C., Hopkins, J. R., Carpenter, L. J., Stanton, J., Read, K. A., and Pilling, M. J.: Sources and sinks of acetone, methanol, and acetaldehyde in North Atlantic marine air, Atmos. Chem. Phys., 5, 1963-1974, doi:10.5194/acp-5-1963-2005, 2005.

MacDonald, R. C. and Kimmerer, T. W.: Ethanol in the stems of trees, Physiol. Plant., 82, 582-588, 1987.

Madronich, S. and Calvert, J. G.: Permutation reactions of organic peroxy radicals in the troposphere, J. Geophys. Res., 95, 56975715,1990 .

Millet, D. B., Goldstein, A. H., Allan, J. D., Bates, T. S., Boudries, H., Bower, K. N., Coe, H., Ma, Y., McKay, M., Quinn, P. K., Sullivan, A., Weber, R. J., and Worsnop, D. R.: VOC measurements at Trinidad Head, CA during ITCT 2K2: Analysis of sources, atmospheric composition and aerosol residence times, J. Geophys. Res., 109, D23S16, doi:10.1029/2003JD004026, 2004.

Millet, D. B., Donahue, N. M., Pandis, S. N., Polidori, A., Stanier, C. O., Turpin, B. J., and Goldstein, A. H.: Atmospheric VOC measurements during the Pittsburgh Air Quality Study: Results, interpretation and quantification of primary and secondary contributions, J. Geophys. Res., 110, D07S07, doi:10.1029/2004JD004601, 2005.

Millet, D. B., Goldstein, A. H., Holzinger, R., Williams, B., Allan, J. D., Jimenez, J. L., Worsnop, D. R., Roberts, J. M., White, A. B., Hudman, R. C., Bertschi, I. T., and Stohl, A.: Chemical characteristics of North American surface layer outflow: Insights from Chebogue Point, Nova Scotia, J. Geophys. Res., 111, D23S53, doi:10.1029/2006JD007287, 2006.
Millet, D. B., Guenther, A., Siegel, D. A., Nelson, N. B., Singh, H. B., de Gouw, J. A., Warneke, C., Williams, J., Eerdekens, G., Sinha, V., Karl, T., Flocke, F., Apel, E., Riemer, D. D., Palmer, P. I., and Barkley, M.: Global atmospheric budget of acetaldehyde: 3-D model analysis and constraints from in-situ and satellite observations, Atmos. Chem. Phys., 10, 3405-3425, doi:10.5194/acp-10-3405-2010, 2010.

Murphy, J. G., Day, D. A., Cleary, P. A., Wooldridge, P. J., Millet, D. B., Goldstein, A. H., and Cohen, R. C.: The weekend effect within and downwind of Sacramento - Part 1: Observations of ozone, nitrogen oxides, and VOC reactivity, Atmos. Chem. Phys., 7, 5327-5339, doi:10.5194/acp-7-5327-2007, 2007.

Nguyen, H. T., Takenaka, N., Bandow, H., Maeda, Y., de Oliva, S. T., Botelho, M. M. F., and Tavares, T. M.: Atmospheric alcohols and aldehydes concentrations measured in Osaka, Japan, and in Sao Paulo, Brazil, Atmos. Environ., 35, 3075-3083, 2001.

Northway, M. J., de Gouw, J. A., Fahey, D. W., Gao, R. S., Warneke, C., Roberts, J. M., and Flocke, F.: Evaluation of the role of heterogeneous oxidation of alkenes in the detection of atmospheric acetaldehyde, Atmos. Environ., 38, 6017-6028, 2004.

Olivier J., Peters, J., Granier, C., Petron, G., Müller, J. F., and Wallens, S.: Present and future surface emissions of atmospheric compounds. POET report \#2, EU project EVK2-1999-00011, 2003.

Poulopoulos, S. G., Samaras, D. P., and Philippopoulos, C. J.: Regulated and unregulated emissions from an internal combustion engine operating on ethanol-containing fuels, Atmos. Environ., 35, 4399-4406, 2001.

Renewable fuels Association Ethanol Industry Outlook, 2006, http: //www.ethanolrfa.org/objects/pdf/outlook/outlook_2006.pdf

Sander, S. P., Finlayson-Pitts, B. J., Friedl, R. R., Golden, D. M., Huie, R. E., Kolb, C. E., Kurylo, M. J., Molina, M. J., Moortgat, G. K., Orkin, V. L., and Ravishankara, A. R.: Chemical Kinetics and Photochemical Data for Use in Atmospheric Studies, Evaluation Number 14, JPL Publication 02-25, Jet Propulsion Laboratory, Pasadena, USA, 2002.

Sander, S. P, Finlayson-Pitts, B. J., Friedl, R. R., Golden, D. M., Huie, Keller-Rudek, H., Kolb, C. E., Kurylo, M. J., Molina, M. J., Moortgat, G. K., Orkin, V. L., Ravishankara, A. R., and Wine, P. H.: Chemical Kinetics and Photochemical Data for Use in Atmospheric Studies, Evaluation Number 15, JPL Publication 06-2, Jet Propulsion Laboratory, Pasadena, USA, 2006.

Schade, G. and Goldstein, A. H.: Fluxes of oxygenated volatile organic compounds from a ponderosa pine plantation, J. Geophys. Res., 106, 3111-3123, 2001.

Schade, G. and Goldstein, A. H.: Plant physiological influences on the fluxes of oxygenated volatile organic compounds from ponderosa pine trees, J. Geophys. Res., 107(D10), 4082, doi:10.1029/2001JD000532, 2002.

Singh, H., Chen, Y., Staudt, A., Jacob, D., Blake, D., Heikes, B., and Snow, J.: Evidence from the Pacific troposphere for large global sources of oxygenated organic compounds, Nature, 410, 1078-1081, 2001.

Singh, H. B., Salas, L., Chatfield, R., Czech, E., Fried, A., Walega, J., Evans, M., Field, B., Jacob, D., Blake, D., Heikes, B., Talbot, R., Sachse, G., Crawford, J., Avery, M., Sandholm, S., and Fuelberg, H.: Analysis of the atmospheric distribution, sources, and sinks of oxygenated volatile organic chemicals based on measurements of the Pacific during TRACE-P, J. Geophys. Res., 109, 
D15S07, doi:10.1029/2003JD003883, 2004.

Singh H. B., Brune, W. H., Crawford, J. H., Jacob, D. J., and Russell, P. B.: Overview of the summer 2004 Intercontinental Chemical Transport Experiment-North America (INTEX-A), J. Geophys. Res., 111, D24S01, doi:10.1029/2006JD007905, 2006.

Singh, H. B., Brune, W. H., Crawford, J. H., Flocke, F., and Jacob, D. J.: Chemistry and transport of pollution over the Gulf of Mexico and the Pacific: spring 2006 INTEX-B campaign overview and first results, Atmos. Chem. Phys., 9, 2301-2318, doi:10.5194/acp-9-2301-2009, 2009.

Spivakovsky, C., Logan, J. A., Montzka, S. A., et al.: Threedimensional climatological distribution of tropospheric $\mathrm{OH}$ : update and evaluation, J. Geophys. Res., 105, 8931-8980, 2000.

Tanner, R. L., Miguel, A. H., De Andrade, J. B., Gaffney, J. S., and Streit, G. E.: Atmospheric chemistry of aldehydes: enhanced peroxyacetyl nitrate formation from ethanol-fueled vehicular emissions, Environ. Sci. Technol., 22, 1026-1034, 1988.

Turquety, S., Logan, J. A., Jacob, D. J., Hudman, R. C., Leung, F. Y., Heald, C. L., Yantosca, R. M., Wu, S., Emmons, L. K., Edwards, D. P., and Sachse, G. W.: Inventory of boreal fire emissions for North America in 2004: the importance of peat burning and pyro-convective injection, J. Geophys. Res., 112, D12S03, doi:10.1029/2006JD007281, 2007.
Villenave, E. and Lesclaux, R.: Kinetics of the cross reactions of $\mathrm{CH}_{3} \mathrm{O}_{2}$ and $\mathrm{C}_{2} \mathrm{H}_{5} \mathrm{O}_{2}$ radicals with selected peroxy radicals, J. Phys. Chem., 34, 14372-14382, 1996.

Warneck, P.: A note on the temperature dependence of Henry's Law coefficients for methanol and ethanol, Atmos. Environ., 40, 7146-7151, 2006.

Warneke, C., Kato, S., de Gouw, J. A., Goldan, P. D., Kuster, W. C., Shao, M., Lovejoy, E. R., Fall, R., and Fehsenfeld, F. C.: Online volatile organic compound measurements using a newly developed proton-transfer ion-trap mass spectrometry instrument during New England Air Quality Study - Intercontinental Transport and Chemical Transformation 2004: Performance, intercomparison, and compound identification, Environ. Sci. Technol., 39, 5390-5397, 2005. 